\title{
Overexpression of heat shock protein 27 (HSP-27) is associated with bad prognosis in oral squamous cell carcinoma
}

\section{Związek nadmiernej ekspresji białka szoku termicznego 27 (HSP-27) ze złym rokowaniem w raku płaskonabłonkowym jamy ustnej}

\author{
Haya Ajalyakeen ${ }^{A-D}$, Mamdouh Almohareb ${ }^{A-E}$, Maher Al-Assaf $^{F}$ \\ Department of Oral Histology and Pathology, Faculty of Dentistry, University of Damascus, Syria \\ A - research concept and design; $B$ - collection and/or assembly of data; $C$ - data analysis and interpretation; \\ $D$ - writing the article; $E$ - critical revision of the article; $F$ - final approval of the article
}

Address for correspondence

Maher Al-Assaf

E-mail: dr.maher.assaf1990@gmail.com

Funding sources

University of Damascus, Syria,

ref. No. 1806/2018 DEN.

Conflict of interest

None declared

Acknowledgements

We would like to declare that all laboratory tests were held at the Department of Oral Histology and Pathology,

Faculty of Dentistry, University of Damascus, Syria.

Received on January 28, 2020

Reviewed on March 1, 2020

Accepted on March 27, 2020

Published online on September 14, 2020

Cite as

Ajalyakeen H, Almohareb M, Al-Assaf M. Overexpression of heat shock protein 27 (HSP-27) is associated with bad prognosis in oral squamous cell carcinoma. Dent Med Probl. 2020;57(3):227-231. doi:10.17219/dmp/119855

DOI

$10.17219 / \mathrm{dmp} / 119855$

Copyright

○) 2020 by Wroclaw Medical University

This is an article distributed under the terms of the

Creative Commons Attribution 3.0 Unported License (CC BY 3.0)

(https://creativecommons.org/licenses/by/3.0/).

\begin{abstract}
Background. Heat shock protein 27 (HSP-27) is a member of the small-molecular-weight HSP family, the expression of which is increased when cells are exposed to elevated temperatures or any other kinds of stress; it seems that the cellular protective properties this protein demonstrates might also help cancer cells stay immortal. Family members of HSPs are either expressed continuously or controlled inductively, and are present in different subcellular structures.

Objectives. The aim of this study was to investigate the prognostic value of HSP-27 expression in the histological grades of oral squamous cell carcinoma (OSCC).

Material and methods. In the present study, HSP-27 expression was compared immunohistochemically among 30 cases with OSCC (15 men and 15 women), ranging between 22 and 74 years of age (mean age: 48 years). The cases were divided into 3 groups $(n=10)$ according to the histological grade.

Results. While all grades expressed HSP-27 in the cancerous epithelial cells, the intensity of expression rose gradually from grade 1 to grade 3 tumors (grade $1<$ grade $2<$ grade 3 ). The statistical analysis indicated significant differences between the 3 groups $(p=0.000)$.

Conclusions. This study has found that HSP-27 may be used as a marker for the histological grades of OSCC and that its expression may be an indicator of the biological behavior of the tumor.
\end{abstract}

Key words: squamous cell carcinoma, heat shock proteins, overexpression

Słowa kluczowe: rak płaskonabłonkowy, białka szoku termicznego, nadmierna ekspresja 


\section{Introduction}

Heat shock proteins (HSPs) are conserved molecular chaperones; they are ubiquitous and have several functions in cellular homeostasis, including the regulation of gene expression, the replication of DNA, the transduction of signals, differentiation, apoptosis, and cellular survival or immortalization. They also protect cells from various kinds of stress, such as hypoxia, ischemia or rapid increases in temperature. ${ }^{1}$

Mammalian HSPs have been arranged into 6 families depending on their molecular size: HSP100, HSP90, HSP70, HSP60, HSP40, and small HSPs (15-30 kDa), including heat shock protein 27 (HSP-27). Family members of HSPs are either expressed continuously or controlled inductively, and they are present in different subcellular structures. ${ }^{2}$

Heat shock protein 27 belongs to the family of small HSPs, which play essential roles in cells under physiological conditions and prevent cells from damage caused by stress. It is a molecular chaperone helping cells remain stable under various stress conditions, such as heat shock, irradiation, oxidative stress, endoplasmic reticulum (ER) stress, and chemotherapy for cancer patients. $^{3}$

Head and neck cancer is one of the most critical malignancies in the world; it is the $3^{\text {rd }}$ most common cancer in developing countries, ${ }^{4,5}$ and squamous cell carcinoma has the highest mortality rate among head and neck cancers (54\%). Therefore, a huge number of oncological studies have been done on this neoplasm so far, ${ }^{4,5}$ with many advances being made in the field of cancer treatment. However, little improvement has been achieved. ${ }^{4,5}$

Tumor grading is related to how similar the cancer tissue is to the parent tissue, and to the ability of the dysplastic squamous epithelial cells to product keratin. The biological behavior of the tumor relates to its histopathological grading. ${ }^{6}$ Additionally, several proteins are called markers and can predict the biological behavior of the tumor. Many studies have been done to assess these markers and their ability to initiate carcinogenesis. ${ }^{7}$

The aim of the present study was to investigate the prognostic value of HSP-27 expression in the histological grades of oral squamous cell carcinoma (OSCC).

\section{Material and methods}

Approval to conduct the study was granted by the Ethics Committee at the University of Damascus in Syria (approval ref.: 1806/2018).

The sample population consisted of 10 formalin-fixed, paraffin-embedded blocks of squamous cell carcinoma in each grade (grades 1-3; a total of 15 men and 15 women at the age of 22-74 years and 10 blocks of normal epithelium (biopsies taken from the mucosa that covers the bone before implantation - the para-keratinized mucosa).

Sections were cut from the blocks, and used for both histological and immunohistochemical examination. Four sections were made and loaded onto slides. The sections were deparaffinized, washed in deionized water and subjected to antigen retrieval. A solution of approx. $3 \%$ hydrogen peroxide was used to block endogenous peroxidase.

The standard streptavidin-biotin-peroxidase complex method was performed to bind the primary antibodies. The reaction products were visualized by treating them with 3,3'-diaminobenzidine (DAB) (Bio SB, Inc., Santa Barbara, USA) solution diluted according to the manufacturer's instructions. The manufacturer's data: Twenty micrometers of DAB chromogen were added to each $1 \mathrm{~mL}$ of poly-detector DAB buffer. For the control samples, the serial sections were treated with all the previous reagents, but without the primary antibody; the samples were confirmed to be unstained.

Heat shock protein 27 was assessed by counting the stained cells in 4 non-overlapping microscopic fields (positive cells showed positivity for the antibody as brown color in the cytoplasm) and by assigning it a score for color intensity ( 0 - no staining; 1 - mild and pale staining; 2 - moderate staining; and 3 - intense staining).

The Kruskal-Wallis and Mann-Whitney tests were used in the statistical analysis. The $\chi^{2}$ test was conducted to determine whether there was a statistically significant difference between the groups: the $X^{2}$ number was 16.057 with a $p$-value of 0.000 (much smaller than 0.05 ). These results refer to the presence of a significant difference between the groups.

\section{Results}

- Normal epithelium $(n=10)$ :

The supra-basal layers of normal epithelium expressed moderately positive staining in almost all 10 samples (Fig. 1).

- OSCC grade $1(n=10)$ :

All cancerous cells showed positive expression for HSP-27 in all 10 samples; the staining was mild and pale (Fig. 2).

- OSCC grade $2(n=10)$ :

All cancerous cells showed positive expression for HSP-27 and the samples were moderately stained with the HSP-27 antibody (Fig. 3).

- OSCC grade $3(n=10)$ :

All cancerous cells showed positive expression for HSP-27, with intense staining in almost all of the samples (Fig. 4). 


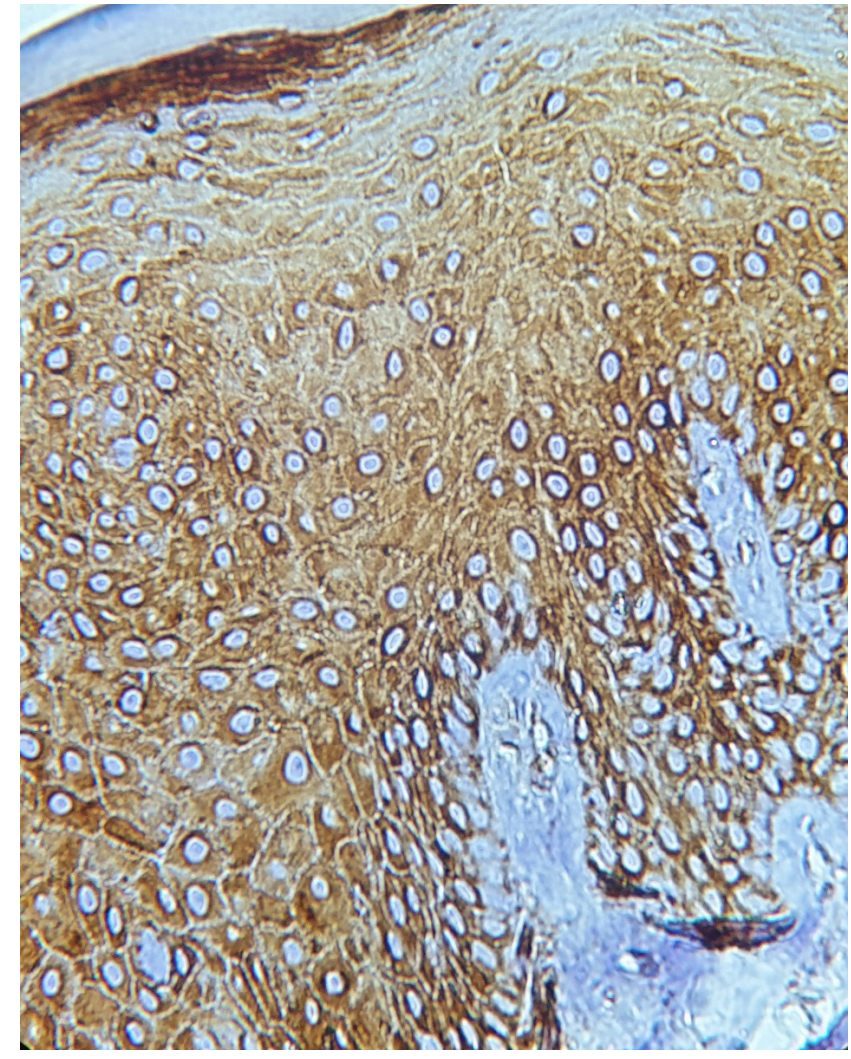

Fig. 1. Moderate positivity for heat shock protein 27 (HSP-27) in the cytoplasm of nearly all epithelial cells in normal mucosa

Magnification $\times 400$.

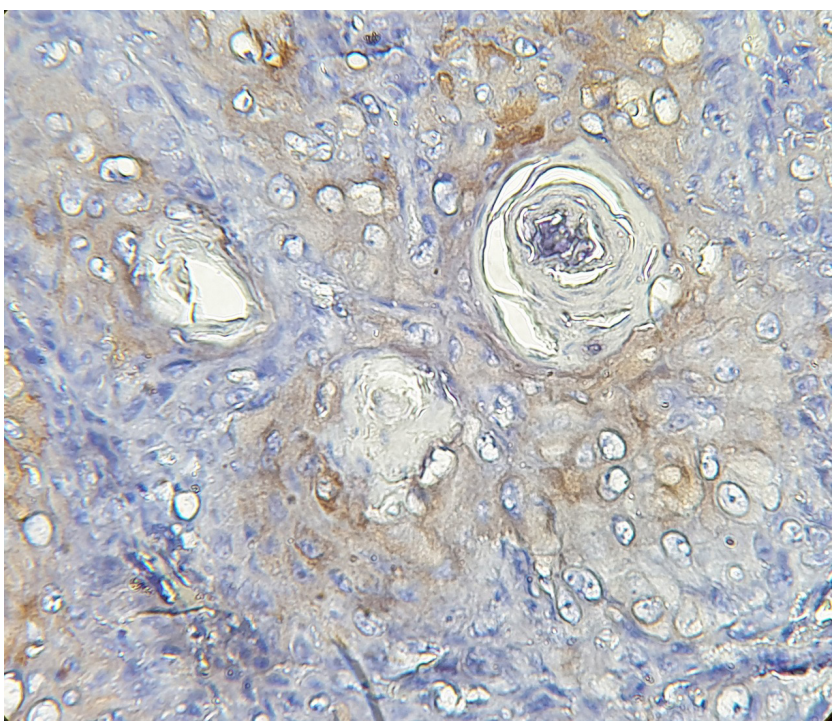

Fig. 2. Mild positivity for heat shock protein 27 (HSP-27) in the cytoplasm of all cancerous cells, grade 1 oral squamous cell carcinoma (OSCC) Magnification $\times 400$.

\section{Discussion}

Head and neck squamous cell carcinoma (HNSCC) is considered the $6^{\text {th }}$ most prevalent cancer in the world. Radiotherapy has been the primary treatment for patients affected with this inoperable disease..$^{8,9}$

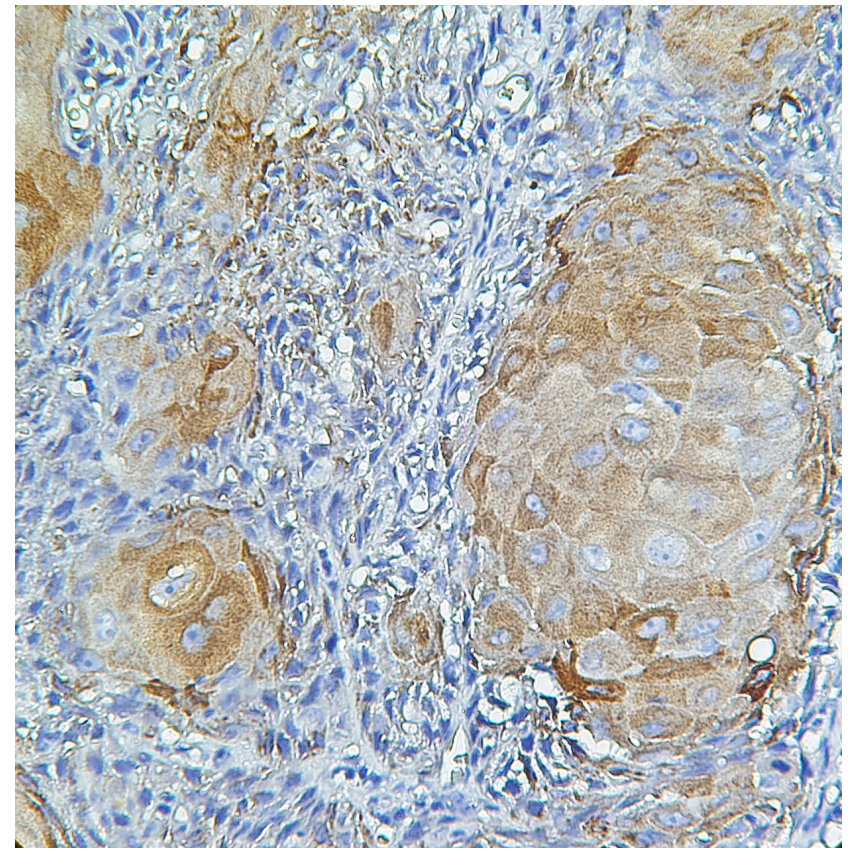

Fig. 3. Moderate positivity for heat shock protein 27 (HSP-27) in the cytoplasm of all cancerous cells, grade 2 oral squamous cell carcinoma (OSCC) Magnification $\times 400$

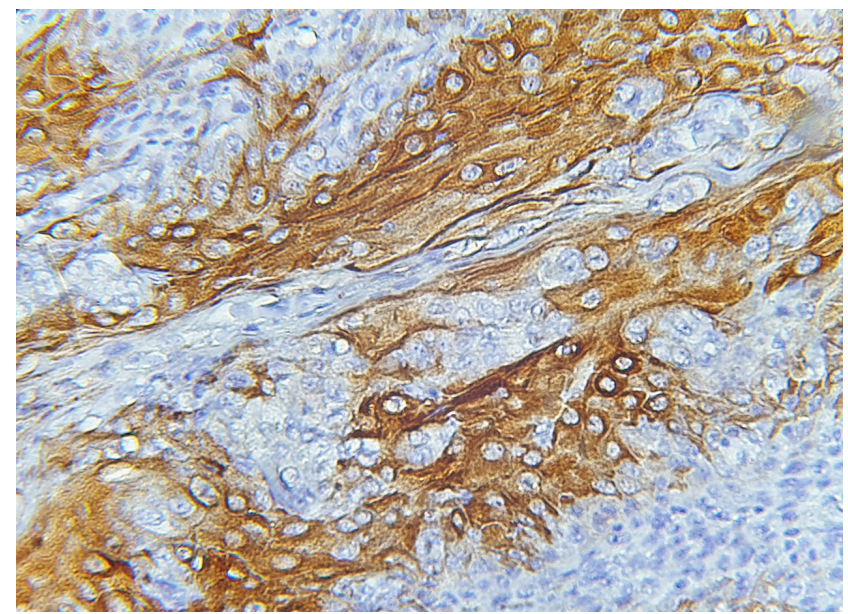

Fig. 4. Intense staining for heat shock protein 27 (HSP-27) in the cytoplasm of nearly all cancerous cells, grade 3 oral squamous cell carcinoma (OSCC) Magnification $\times 400$.

In spite of these huge improvements, the lowest 5-year survival rate associated with HNSCC has remained the same, due to frequent recurrence after the initial therapy. Therefore, advanced therapeutic methods should be applied to defeat resistance to anticancer therapy. One option suggests suppressing specific physiological proteins with antiapoptotic roles, such as HSP-27. The overexpression of this protein has been detected in many cancers, including breast cancer, ${ }^{10,11}$ prostate cancer ${ }^{12,13}$ and gastric cancer. ${ }^{14,15}$

Heat shock protein 27 has also been found to be overexpressed in HNSCC cases. ${ }^{5}$ In addition, HSP-27 has been associated with the most serious behaviors of cancer cells - metastasis, ${ }^{16,17}$ short survival time ${ }^{10}$ and poorly differentiated cells. ${ }^{18}$ With its antiapoptotic property, HSP-27 
causes the resistance of cancer cells to chemoradiotherapy. ${ }^{19,20}$ Heat shock protein 27 plays a protective role for tumor cells against oxidative pressure with the unique ability of glucose-6-phospate-dehydrogenase to keep glutathione in its decreased form, and also with the activity of an in vivo chaperone against oxidized proteins. ${ }^{21}$ Therefore, decreasing the antioxidant protection of tumor cells through HSP-27 suppression should augment the benefit of the cytotoxic competence of radiotherapy and enhance the clinical outcome.

Apart from that, HSP-27 participates in the regulation of Akt (serine/threonine kinase), which is an important indicator molecule for cell survival. ${ }^{22}$

Heat shock protein 27 plays an essential role in the chemoresistance of the squamous cell carcinoma of the tongue (SCCT) cells via its extracellular and intracellular signaling process. Heat shock protein 27 could serve as a useful biomarker and a precise therapeutic target in the treatment of SCCT. ${ }^{23}$

There has been a particular increase in the amount of HSP-27 in multidrug-resistant SCCT cells. Both HSP-27 knockdown and anti-HSP-27 antibody treatment oppose chemoresistance. Inversely, the overexpression of HSP-27 and recombinant human HSP-27 treatment increase chemoresistance.

Furthermore, chemotherapy has been reported to have a significant effect on the HSP-27 levels by inducing the protein in SCCT cells and their culture medium as well as in the tumor tissues and serum of SCCT patients. For that, the overexpression of HSP-27 can predict the poor outcome of SCCT patients receiving chemotherapy; specifically, extracellular HSP-27 binding with toll-like receptor 5 (TLR5) and the activation of nuclear factor kappa $\mathrm{B}(\mathrm{NF}-\mathrm{kB})$ signaling keep cancer cells alive. Toll-like receptor 5 knockdown or the level of the restored inhibitor of NF-kB (I $\mathrm{KB} \alpha)$ damage extracellular HSP-27-induced $\mathrm{NF}-\mathrm{kB}$ transactivation and chemoresistance. Additionally, the action of intracellular HSP-27 binding to BAX and BIM prevents their translocation to the mitochondria, and cytochrome $\mathrm{C}$ is subsequently released under chemotherapy, which causes the suppression of the mitochondrial apoptotic pathway. ${ }^{23}$

Moreover, some studies have reported the overexpression of HSP-27 in cancer stem cells. One group of researchers showed the augmented expression and phosphorylation of the protein in breast cancer stem cells. ${ }^{11}$ They revealed that HSP-27 had to play a role in the epithelial-mesenchymal transition process to help with the maintenance of cancer stem cells. ${ }^{11}$ Another study illustrated that lung cancer stem cells had elevated levels of the activated type of HSP-27 due to superoxide and traditional chemotherapy treatment. ${ }^{24}$

The expression of HSP-27 in well-differentiated OSCCs was significantly lower than in moderately differentiated OSCCs $(p=0.000)$, and in moderately differentiated OSCCs, the expression was lower than in poorly differentiated OSCCs $(p=0.002)$. The analysis showed a clear correlation between the expression of HSP-27 and the histopathological grade of OSCC $(p=0.000)$ (Table 1 , Fig. 5). We attribute this to the major role of the protein as an anti-apoptosis agent helping cancerous cells remain immortal.

Table 1. Binary comparison of the intensity of heat shock protein 27 (HSP-27) in the histological grades of oral squamous cell carcinoma (OSCC)

\begin{tabular}{|c|c|c|c|c|}
\hline Sample 1 & Sample 2 & U-value & $p$-value & Differentiation \\
\hline OSCC grade 1 & OSCC grade 2 & 4.5 & 0.000 & significant differences \\
OSCC grade 1 & OSCC grade 3 & 1 & 0.000 & significant differences \\
OSCC grade 2 & OSCC grade 3 & 15 & 0.002 & significant differences \\
\hline
\end{tabular}

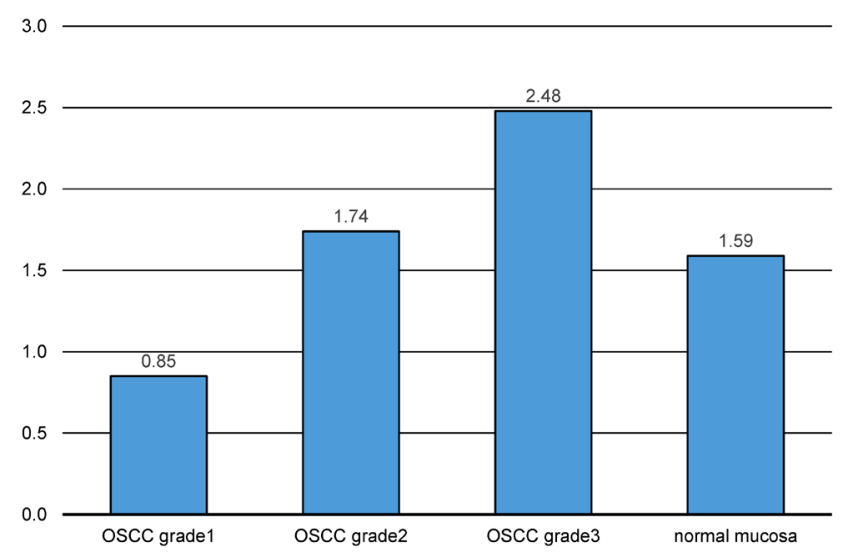

Fig. 5. Intense levels of heat shock protein 27 (HSP-27)

These findings are in agreement with previous studies, e.g., by Lambot et al., who investigated HSP-27 expression in esophagitis, esophagus dysplasia, and the 3 grades of esophagus squamous cell carcinoma in comparison with the normal epithelium of the esophagus. ${ }^{25}$ The study concluded that there was a clear relationship between high HSP-27 expression and the atypia of cells. ${ }^{25}$ Also, a study by Mese et al., which was conducted on biopsies from both OSCC areas and metastasis areas in different parts of the body, reported results similar to ours, with a stronger expression of the protein for metastasis biopsies. ${ }^{26}$ Muzio et al. conducted research with exactly opposite results. $^{27}$ The correlation was between low-grade OSCC and the intensity of HSP-27 expression. We relate this to the variation of standards in the 2 studies, as they used biopsies taken from patients who had already gone through multiple types of treatment whereas our samples were taken and studied before any treatment.

\section{Conclusions}

This study has found that HSP-27 can be used as a marker for the histological grades of OSCC and that its expression is a possible indicator of the biological behavior of the tumor. 


\section{ORCID iDs}

Haya Ajalyakeen (1) https://orcid.org/0000-0002-3247-7992

Mamdouh Almohareb (D) https://orcid.org/0000-0003-3265-7309

Maher Al-Assaf (D) https://orcid.org/0000-0001-6691-6992

\section{References}

1. Arrigo AP. Human small heat shock proteins: Protein interactomes of homo-and hetero-oligomeric complexes: An update. FEBS Lett. 2013;587(13):1959-1969.

2. Jego G, Hazoumé A, Seigneuric R, Garrido C. Targeting heat shock proteins in cancer. Cancer Lett. 2013;332(2):275-285.

3. Ma W, Teng Y, Hua H, Hou J, Luo T, Jiang Y. Upregulation of heat shock protein 27 confers resistance to actinomycin D-induced apoptosis in cancer cells. FEBS J. 2013;280(18):4612-4624.

4. Gnepp DR. Diagnostic Surgical Pathology of the Head and Neck $2^{\text {nd }}$ ed. eBook. Philadelphia, PA: Saunders (Elsevier Health Sciences); 2009:179-181.

5. Lo WY, Tsai MH, Tsai Y, et al. Identification of over-expressed proteins in oral squamous cell carcinoma (OSCC) patients by clinical proteomic analysis. Clin Chim Acta. 2007;376(1-2):101-107.

6. Neville BW, Damm DD, Allen CM, Chi AC. Oral and Maxillofacial Pathology. $4^{\text {th }}$ ed. Philadelphia, PA: Saunders (Elsevier Health Sciences); 2015:252-255.

7. Deyhimi P, Azmoudeh F. HSP27 and HSP70 expression in squamous cell carcinoma: An immunohistochemical study. Dent Res J (Isfahan). 2012;9(2):162-166.

8. Zaid KW, Chantiri M, Bassit G. Recombinant human bone morphogenetic protein-2 in development and progression of oral squamous cell carcinoma. Asian Pac J Cancer Prev. 2016;17(3):927-932.

9. Bourhis J, Etessami A, Lusinchi A. New trends in radiotherapy for head and neck cancer. Ann Oncol. 2005;16(Suppl 2):ii255-ii257.

10. Thanner F, Sütterlin MW, Kapp M, et al. Heat shock protein 27 is associated with decreased survival in node-negative breast cancer patients. Anticancer Res. 2005;25(3A):1649-1653.

11. Wei L, Liu TT, Wang HH, et al. Hsp27 participates in the maintenance of breast cancer stem cells through regulation of epithelial -mesenchymal transition and nuclear factor-kB. Breast Cancer Res. 2011;13(5):R101.

12. Miyake H, Muramaki M, Kurahashi T, Yamanaka K, Hara I, Fujisawa M. Enhanced expression of heat shock protein 27 following neoadjuvant hormonal therapy is associated with poor clinical outcome in patients undergoing radical prostatectomy for prostate cancer. Anticancer Res. 2006;26(2B):1583-1587.

13. Cordonnier T, Bishop JL, Shiota M, et al. Hsp27 regulates EGF/ $\beta$-catenin mediated epithelial to mesenchymal transition in prostate cancer. Int J Cancer. 2015;136(6):E496-E507.

14. Kapranos N, Kominea A, Konstantinopoulos PA, et al. Expression of the 27-kDa heat shock protein (HSP27) in gastric carcinomas and adjacent normal, metaplastic, and dysplastic gastric mucosa, and its prognostic significance. J Cancer Res Clin Oncol. 2002;128(8):426-432.

15. Ge H, He X, Guo L, Yang X. Clinicopathological significance of HSP27 in gastric cancer: A meta-analysis. Onco Targets Ther. 2017;10:4543-4551.

16. Storm FK, Mahvi DM, Gilchrist KW. Heat shock protein 27 overexpression in breast cancer lymph node metastasis. Ann Surg Oncol. 1996;3(6):570-573.

17. Pavan S, Musiani D, Torchiaro E, et al. HSP27 is required for invasion and metastasis triggered by hepatocyte growth factor. Int J Cancer. 2014;134(6):1289-1299.

18. Romani AA, Crafa P, Desenzani S, et al. The expression of HSP27 is associated with poor clinical outcome in intrahepatic cholangiocarcinoma. BMC Cancer. 2007;7(1):232.

19. Teimourian $S$, Jalal R, Sohrabpour M, Goliaei B. Down-regulation of Hsp27 radiosensitizes human prostate cancer cells. Int J Urol. 2006;13(9):1221-1225.

20. Vargas-Roig LM, Gago FE, Tello O, Aznar JC, Ciocca DR. Heat shock protein expression and drug resistance in breast cancer patients treated with induction chemotherapy. Int J Cancer. 1998;79(5):468-475.

21. Préville $X$, Salvemini $F$, Giraud $S$, et al. Mammalian small stress proteins protect against oxidative stress through their ability to increase glucose-6-phosphate dehydrogenase activity and by maintaining optimal cellular detoxifying machinery. Exp Cell Res. 1999;247(1):61-78.
22. Wu R, Kausar $H$, Johnson $P$, Montoya-Durango DE, Merchant $M$, Rane MJ. Hsp27 regulates Akt activation and polymorphonuclear leukocyte apoptosis by scaffolding MK2 to Akt signal complex. J Biol Chem. 2007;282(30):21598-21608.

23. Zheng G, Zhang Z, Liu H, et al. HSP27-mediated extracellular and intracellular signaling pathways synergistically confer chemoresistance in squamous cell carcinoma of tongue. Clin Cancer Res. 2018;24(5):1163-1175.

24. Hsu HS, Lin JH, Huang WC, et al. Chemoresistance of lung cancer stemlike cells depends on activation of Hsp27. Cancer. 2011;117(7):1516-1528.

25. Lambot MA, Peny MO, Fayt I, Haot J, Noël JC. Overexpression of 27-kDa heat shock protein relates to poor histological differentiation in human oesophageal squamous cell carcinoma. Histopathology. 2000;36(4):326-330.

26. Mese H, Sasaki A, Nakayama S, et al. Prognostic significance of heat shock protein 27 (HSP27) in patients with oral squamous cell carcinoma. Oncol Rep. 2002;9(2):341-344.

27. Muzio LL, Campisi G, Farina A, et al. Prognostic value of HSP27 in head and neck squamous cell carcinoma: $A$ retrospective analysis of 57 tumours. Anticancer Res. 2006;26(2B):1343-1349. 
